\title{
Creatine kinase and $\mathrm{C}$ reactive protein as an indicator for tissue damage in the retained placenta in cows
}

\author{
B.D. Al-Watar $\mathbb{1}$, E.H. Lazim ${ }^{\mathbb{C}}$ and O.H. Al-Hyani ${ }^{\mathbb{C}}$ \\ Department of Surgery and Theriogenology, College of Veterinary Medicine, University of Mosul, Mosul, Iraq
}

\begin{tabular}{l} 
Article information \\
\hline Article history: \\
Received January 03, 2020 \\
Accepted March 05, 2020 \\
Available online November 1, 2020 \\
\hline Keywords: \\
CK \\
CRP \\
Tissue damage \\
Retained placenta \\
Cow \\
\hline
\end{tabular}

Correspondence:

B.D. Al-Wataar

dr.barra1980@uomosul.edu.iq

\begin{abstract}
The current study aimed to investigate concentrations of Creatine Kinase (CK) and C Reactive Protein (CRP) in blood serum of cows with the retained placenta to compare with cows of normal parturition, also, to compare their concentrations in association with fetal sex, previous parturition and time to placenta expel. A total of sixty-three cows suffered from retained placenta with cows of normal parturition $(n=10)$ were included in the current study during the period starting from December 2018 till September 2019. Blood samples $(10 \mathrm{ml})$ were collected from the jugular vein to determine the concentration of CRP and CK in blood serum by enzyme-linked immunosorbent assay (ELIZA). The result showed that the serum concentrations of CRP and CK in cows suffering from retained placenta was $28.03 \mu \mathrm{g} / \mathrm{ml}$ and $238.93 \mathrm{ng} / \mathrm{ml}$ significantly higher than in cows with normal parturition $22.80 \mu \mathrm{g} / \mathrm{ml}$ and $137.50 \mathrm{ng} / \mathrm{ml}$. The result of ELIZA showed that the serum concentration of CRP and CK in cows did not significantly affect depending upon the sex of the fetus and previous parturition history. On other hands, the serum concentration of CRP and CK in cows significantly differed depending upon the time to expel the placenta. In conclusion, the serum concentration of CRP and CK in cows with retained placenta was markedly higher than recorded in cows with normal parturition, and this can be used to identify days past since cows with retained placenta and to give a prognosis for their health and reproductive status.
\end{abstract}

DOI: 10.33899/ijvs.2020.126496.1338, (C2021, College of Veterinary Medicine, University of Mosul.

This is an open access article under the CC BY 4.0 license (http://creativecommons.org/licenses/by/4.0/).

\section{Introduction}

$\mathrm{C}$ reactive protein $(\mathrm{CRP})$ is a ring shape protein that synthesis and release from the liver with fibrinogen in response to the production of interleukin six released from stimulated macrophages, $\mathrm{T}$ lymphocytes and adipocytes by dying or dead cell due to a wide range of inflammatory process either acute or even chronic reaction, also due to rheumatic arthritis, pathogenic microorganisms, lethal or sublethal cellular injury (1). CRP is a member of patterns recognition receptor (PRR) system that responsible for the detection of necrotic, apoptotic cells as well as pathogenic microorganisms (especially bacterial pathogens), in which CRP where bind to lysophosphatidylcholine (lysolecithins) on the cell membrane of dead and dying cells, this lysolecithins were synthesis by hydrolysis of lipids present on the cell membrane by the action of phospholipase (especially phospholipase A2 enzyme) that released from affected cells, these complex of CRP with lysolecithins will cause activation $400 \mathrm{kDa}$ complement compound known as $\mathrm{C} 1 \mathrm{q}$ that lead to initiation and ignition of the complement system to promote and activate phagocytosis conducted by macrophages to necrotic and apoptotic cells (2). Creatine kinase $(\mathrm{CK})$ is a crystal shape enzyme synthesis in a wide range of cells especially those of high consuming ATP as a source for energy in muscle, brain, retina, ear, spermatogenesis process and graved placenta (3). CK function is to catalyzes a reversible conversion of creatine to phosphocreatine and ADP using ATP as a source of energy in response to high energy-consuming in situ within cells these can be attributed to fast intracellular transportation to phosphocreatine as a source of energy in which 
phosphocreatine can react with ADP to produce ATP and creatine in the presence of CK enzyme for fast intracellular energy transportation, also, CK has main three subtypes, brain $\mathrm{CK}(\mathrm{CKb})$, muscle $\mathrm{CK}(\mathrm{CKm})$ and mitochondrial $\mathrm{CK}$ (CKmt) (4). CK concentration increases during cellular damage occur in tissue rich with CK especially muscle as in cases of myocardial infarction, rhabdomyolysis and myositis, in which destruction of these cells for any cellular injuries lead to releasing of CK into the bloodstream and increase its level in blood serum (5). Retention of fetal membranes in cows occurs when the uterus fails to expel the fetus covering membranes after one day of calving, which usually occurs within 4-6 hours after parturition. The occurrence of such case in cows could be affected by many factors; mainly types of parturition (normal or dystocia), sex and size of the fetus, twin's deliveries, number of previous parturitions, abortion and nutritional status of cows (6). Naturally, the retained placenta will be expelled with four to six hours after parturition (7).

The objective of this study was to investigate the serum concentration of CRP and CK in cows that suffered from retention of the placenta as an indicator of tissue damage and the relationship between CRP and CK with the type of parturition process, sex of the fetus, previous calve delivery and days required to expel the placenta.

\section{Materials and methods}

\section{Animals and blood samples}

A total of sixty-three cows aged from two to seven years, suffering from retention of placenta. Another ten cows (control group) with normal parturition and expulsion of the placenta within three to six hours were also used in the current study during the period from December 1, 2018, till September 1, 2019. Blood samples were collected from jugular veins $(10 \mathrm{ml})$ using a round gel tube with clot activator. The blood samples were left for 30 minutes to allow the blood clot to be formed and to separate serum, later blood clot removed by centrifuge at $2500 \mathrm{rpm}$ for 20 minutes. Using Pasteur pipette, the serum was collected, transported to Eppendorf tubes and stored at $-20{ }^{\circ} \mathrm{C}$ in the freezer.

\section{The serum concentration of CRP and $\mathrm{CK}$ in cows}

The concentrations of CRP and CK in blood's serum were estimated by direct ELIZA kits obtained from Monobind Inc, USA. Estimation of the CRP concentration $(\mu \mathrm{g} / \mathrm{ml})$ was measured following methods described by Kimberly et al. (8). In contrast, the concentration of $\mathrm{CK}(\mathrm{ng} / \mathrm{ml})$ was determined by using the procedure described by Panteghini et al. (9).

\section{Statistical analysis}

The mean concentration of CRP and CK were statistically analyzed using SPSS software version 19.0. A one-way analysis of variance was used to explain the signification differences according to experiment design. Duncan's test used as a post hock test to identify the significant differences in serum concentration of CRP and $\mathrm{CK}$ in relation to previous parturition and time to retained placenta at $\mathrm{P}<0.05$. In addition to independent sample $t$-test were used to identify the significant differences in serum concentration of CRP and CK in relation to the type of parturition and gender of the fetus. All statistical analyses were conducted at $\mathrm{P}<0.05$.

\section{Results}

\section{Type of parturition}

Significant differences were detected for CRP and CK serum levels between normal parturition and retained placenta. CRP and CK levels were higher in cases of parturition associated with the retained placenta in comparison to those of normal parturition in cows (Table 1).

Table 1: Effect of parturition type on serum concentration of CRP and CK

\begin{tabular}{lcc}
\hline \multirow{2}{*}{ Type of parturition } & \multicolumn{2}{c}{ Mean \pm St. error } \\
\cline { 2 - 3 } & CRP $(\mu \mathrm{g} / \mathrm{ml})$ & CK $(\mathrm{ng} / \mathrm{ml})$ \\
\hline Normal Parturition & $22.80 \pm 2.01^{*}$ & $137.50 \pm 7.41^{*}$ \\
Retained placenta & $28.03 \pm 2.62^{*}$ & $238.93 \pm 6.87^{*}$ \\
\hline
\end{tabular}

$*$ there are significant differences within the groups in the same parameter at $\mathrm{P}<0.05$.

\section{Gender of fetus}

The result represented in table 2 showed that there were no significant differences in serum concentrations of CRP and CK in cows whatever the born calf sex was (male or female). Still, the serum concentrations of CRP and CK in cows that have male or female calves with retained placenta were significantly higher concentration in comparison with cows that have male or female calves without retention of placenta.

\section{Previous parturitions}

The result present in table 3 showed that the serum concentration of CRP and CK did not significantly differ in relation to previous parturition status of cows with retained placenta.

\section{Time of retained placenta}

The result of table 4 showed that the serum concentration of CRP and CK were increased significantly when there was an increase in time that required till placenta expel, in which the highest serum concentration of CRP and CK were recorded in cows with the retained placenta after four days. The serum concentration of CRP and CK were decreased significantly when the time to expel placenta has been reduced. 
Iraqi Journal of Veterinary Sciences, Vol. 35, No. 1, 2021 (163-167)

Table 2: Effect of fetal sex on serum concentration of CRP and CK

\begin{tabular}{lcccc}
\hline \multirow{2}{*}{ Fetus sex } & \multicolumn{4}{c}{ Mean \pm St. error } \\
\cline { 2 - 5 } & \multicolumn{2}{c}{ CRP $(\mu \mathrm{g} / \mathrm{ml})$} & Male & CK $(\mathrm{ng} / \mathrm{ml})$ \\
\cline { 2 - 5 } & Male & Female & $138.49 \pm 4.78^{*}$ & $137.17 \pm 3.48^{*}$ \\
Normal Parturition & $23.45 \pm 1.05^{*}$ & $23.01 \pm 1.43^{*}$ & $239.19 \pm 3.65^{*}$ & $240.09 \pm 8.17^{*}$ \\
Retained placenta & $27.07 \pm 1.71^{*}$ & $27.94 \pm 1.94^{*}$ &
\end{tabular}

* there is a significant difference within the groups in same-sex at $\mathrm{P}<0.05$.

Table 3: Effect of previous parturitions on serum concentration of CRP and CK

\begin{tabular}{lll}
\hline \multirow{2}{*}{ Previous parturitions } & \multicolumn{2}{l}{ Mean \pm St. error } \\
\cline { 2 - 3 } & CRP $(\mu \mathrm{g} / \mathrm{ml})$ & $\mathrm{CK}(\mathrm{ng} / \mathrm{ml})$ \\
\hline Heifers & $32.07 \pm 3.06^{\mathrm{a}}$ & $203.75 \pm 2.32^{\mathrm{a}}$ \\
Previous one parturition & $32.67 \pm 1.06^{\mathrm{a}}$ & $237.01 \pm 3.00^{\mathrm{a}}$ \\
Previous two parturition & $39.33 \pm 1.86^{\mathrm{a}}$ & $222.61 \pm 3.31^{\mathrm{a}}$ \\
Previous three parturition & $31.95 \pm 2.13^{\mathrm{a}}$ & $247.31 \pm 1.10^{\mathrm{a}}$ \\
Previous four parturition & $38.67 \pm 1.02^{\mathrm{a}}$ & $208.50 \pm 3.49^{\mathrm{a}}$ \\
Previous five parturition & $38.05 \pm 4.02^{\mathrm{a}}$ & $230.09 \pm 8.71^{\mathrm{a}}$ \\
Previous six parturition & $34.67 \pm 3.93^{\mathrm{a}}$ & $234.67 \pm 1.07^{\mathrm{a}}$ \\
\hline
\end{tabular}

The different vertical letter means there is a significant difference within the groups in the same parameter at $\mathrm{P}<0.05$.

Table 4: Effect of time to expel placenta on serum concentration of CRP and CK

\begin{tabular}{lll}
\hline Placenta expel time & \multicolumn{2}{l}{ Mean \pm St. error } \\
\cline { 2 - 3 } (retention length/day) & $\mathrm{CRP}(\mu \mathrm{g} / \mathrm{ml})$ & $\mathrm{CK}(\mathrm{ng} / \mathrm{ml})$ \\
\hline One day & $26.73 \pm 1.49^{\mathbf{c}}$ & $216.35 \pm 1.19^{\mathbf{d}}$ \\
Two days & $33.67 \pm 1.31^{\mathbf{b c}}$ & $222.36 \pm 1.97^{\mathbf{c}}$ \\
Three days & $39.33 \pm 1.86^{\mathbf{b}}$ & $240.09 \pm 5.67^{\mathbf{b}}$ \\
Four days & $44.57 \pm 1.51^{\mathbf{a}}$ & $274.86 \pm 5.53^{\mathbf{a}}$ \\
\hline The different vertical letter means there is a significant \\
difference within the groups in the same parameter at \\
$\mathrm{P}<0.05$.
\end{tabular}

\section{Discussion}

The result of the current study showed that the serum concentration of CRP and CK was elevated significantly in the cows suffered from the retained placenta in comparison with those cows of expected parturition. These results indicate that status of the retained placenta will result in cellular damages and inflammatory process in placenta and uterus of affected animals, which lead to significant elevations in serum concentration of CRP and CK (10). These results agreed with other studies that indicate that most common squealy and complications of retention of fetal membranes as endometritis, mastitis and paralysis (11-13). Endometritis and mastitis associated with retained placenta will cause an increase in the level of acute-phase protein especially CRP which increase in response to increase in IL6 secretion from macrophages and lymphocytes in the retained placenta, the rise in CRP secretions will bind to specific molecules on dying cell surface of apoptotic cells to facilitate and assist macrophages to phagocytosis these affect cells present in the placenta to decrease the risk of infection and inflammation that can be established in the placenta during retained placenta (14). Also, CK concentration level in serum of cow suffering from retained placenta was increased due to placenta cellular damages lead to releasing these biochemical components into the bloodstream, in which uterus and placenta were rich with $\mathrm{CK}$ as a source to reversible energy-saving (15). The serum concentration of CRP and CK in cows with retained placenta didn't affect with the sex of calves, in which the concentration of CRP and CK in serum showed no significant difference, in contrast, the serum concentration of CRP and CK in cows suffering from retained placenta with calves either male and females were significantly higher than that recorded in a cow with male and female calves with normal parturition, this indicates that the sex of calves didn't have any effect on the concentration of these biochemical molecules from cows suffering from the retained placenta $(14,15)$. The concentration of CRP in serum of pregnant and parturiated cows affect mainly with infectious diseases especially ischemia, inflammation and cell injury (16), while the concentration of CK increase in cases hypocalcemia, muscle damages, and endometritis $(17,18)$, the effect of high serum concentration of CRP and $\mathrm{CK}$ in in cows with retained placenta can lead to prevent or decrease transportation of immunoglobulins from dams to their calves through colostrum significantly when the concentration of CK were increased in blood serum (19), these high level of CK in blood serum will cause increase in cortisol secretion in bloodstream which lead to decrease in immunoglobulins formation and secretions (20), also increase CRP concentration in blood serum will prevent transportation of immunoglobulin from dams to calves through colostrum, these mechanism conducted by CRP to act as opsonic elements which bind to Fc receptors and prevent transport immunoglobulins to calves through colostrum which is the main side effect of high serum concentrations of CRP and CK in case of retained placenta in animals $(21,22)$. The result of current study showed that the number of previous calving associated with retained placenta didn't affect the serum concentration of CRP and $\mathrm{CK}$ in, in contrast, the previous parturition status will affect the frequencies of retained placenta occurrence, were it's with highest incidence in heifers and in cows characterized 
by small size of both external genital organs and pelvic bones (23). The results of current study indicate that the increasing of time that consumed to expel placenta were significantly related to increase in concentration of CRP and CK in serum, this will be associated with cellular damages that lead to increase in serum concentration of CRP and CK in cows $(14,15)$.

\section{Conclusion}

In conclusion, the concentration of CRP and CK in the blood of cows suffering from retained placenta was significantly higher than recorded in cows with normal parturition, this information can be used to identify days past since cows suffered from the retained placenta and to give a prognosis for their health and reproductive status.

\section{Acknowledgement}

The authors wish to declare their appreciation to the College of Veterinary Medicine, the University of Mosul for supporting authors and current subject work.

\section{Conflict of interest}

The author declares that there is no conflict of interest regarding trails, publishing or funding this manuscript.

\section{References}

1. Sproston NR, Ashworth JJ. Role of c-reactive protein at sites of inflammation and infection. Front Immunol. 2018;13(9):754. doi: 10.3389/fimmu.2018.00754

2. Tothova C, Nagy O, Kovac G. Acute phase proteins and their use in the diagnosis of diseases in ruminants: A review. Vet Med. 2014;59(4):163-80. doi: 10.17221/7478-vetmed

3. Iazab MFA. Evaluation of serum enzyme activities and protein fractions in Brucella-infected cows. Turk J Vet Anim Sci. 2015; 39:480-484. doi: $10.3906 /$ vet-1504-31

4. Khan A, Rathore B. Total creatine kinase and its isoenzymes in cord blood of full-term newborns. EJMR. 2017;4(1):10-21. doi: 10.24041/ejmr2017.3

5. Sattler T, Furll M. creatine kinase and aspartate aminotransferase in cows as indicators for endometritis. J Vet Med. 2004;51(3):132-137. doi: $10.1111 / \mathrm{j} .1439-0442.2004 .00612 . \mathrm{x}$

6. Mee JF. Prevalence and risk factors for dystocia in dairy cattle: A review. Vet J. 2008;176(1):93-101. doi: 10.1016/j.tvjl.2007.12.032

7. Hopper RM. Bovine Reproduction. New York: Wily Blackwell; 2014. 32-49 p.

8. Kimberly MM. Standardization of immunoassays for measurement of high-sensitivity c-reactive protein. phase i: evaluation of secondary reference materials. Clin Chem. 2003; 49(4):611-616. doi: $10.1373 / 49.4 .611$

9. Panteghini M. Creatine kinase MB isoforms. J Clin Immunoassay. 1994; 17:30-4

10. Brodzki P, Kostro K, Brodzki A, Wawron W, Marczuk J, Kurek L. Inflammatory cytokines and acute-phase proteins concentrations in the peripheral blood and uterus of cows that developed endometritis during early postpartum. Theriogenol. 2015;84(1):11-18. doi: 10.1016/j.theriogenology.2015.02.006
11. Poulton P, Fisher A, Mansell P, Pyman M. Clinical findings from 104 cases of calving paralysis in dairy cows from Gippsland, Australia. N Z Vet J. 2019;67(4):214-218. doi: 10.1080/00480169.2019.1602086

12. Eckersall PD, Young FJ, McComb C, Hogarth CJ, Safi S, Fitzpatrick JL. Acute phase proteins in serum and milk from dairy cows with clinical mastitis. Vet Rec. 2001;148(2):35-41. doi: 10.1136/vr.148.2.35

13. Tothova C, Nagy O, Kovac G. Acute phase proteins and their use in the diagnosis of diseases in ruminants: A review. Vet Med. 2014;59(4):163-80. doi: 10.17221/7478-vetmed

14. Hozyasz KK, Szymanski M, Bielecka M. Fever and high c-reactive protein level as the sole manifestation of allergy to cow milk. Explore. 2006;2(6):520-521. doi: 10.1016/j.explore.2006.08.001

15. Sheldon IM, Owens SE. Postpartum uterine infection and endometritis in dairy cattle. Anim Reprod. 2017;14(3):622-629. doi: 10.21451/1984-3143-ar1006

16. Tthov C, Nagy O, Kov G. Acute Phase Proteins. $1^{\text {st }}$ ed. New York: InTech Press; 2013. 103-116 p. doi: 10.5772/55857

17. Gelfert CC, Alpers I, Dallmeyer M, Decker M, Hüting A, Lesch S, Staufenbiel R. Factors affecting the success rate of treatment of recumbent dairy cows suffering from hypocalcaemia. J Vet Med. 2007;54(4):191-198. doi: 10.1111/j.1439-0442.2007. 00940.x

18. Sattler T, Furll M. creatine kinase and aspartate aminotransferase in cows as indicators for endometritis. J Vet Med. 2004;51(3):132-137. doi: 10.1111/j.1439-0442.2004.00612.x

19. Hulbert LE, Moisa SJ. Stress, immunity, and the management of calves. J Dairy Sci. 2016;99(4):3199-3216. doi: 10.3168/jds.2015-10198

20. Pearson JM, Homerosky ER, Caulkett NA, Campbell JR, Levy M, Pajor EA, Windeyer MC. Quantifying subclinical trauma associated with calving difficulty, vigour, and passive immunity in newborn beef calves. Vet Rec Open. 2019; 6(1): e000325. doi: 10.1136/vetreco-2018000325

21. Argüello A, Castro N, Capote J, Tyler JW, Holloway NM. Effect of colostrum administration practices on serum IgG in goat kids. Livest Prod Sci. 2004;90(2-3):235-239. doi: 10.1016/j.livprodsci.2004.06.006

22. Schroedl W, Jaekel L, Krueger M. C reactive protein and antibacterial activity in blood plasma of colostrum-fed calves and the effect of lactulose. J Dairy Sci. 2003;86(10):3313-3320. doi: 10.3168/jds.s00220302(03)73933-2

23. Zaborski D, Grzesiak W, Szatkowska I, Dybus A, Muszynska M, Jedrzejczak M. Factors affecting dystocia in cattle. Reprod Domest Anim. 2009;44(3):540-551. doi: 10.1111/j.1439-0531.2008.01123.x

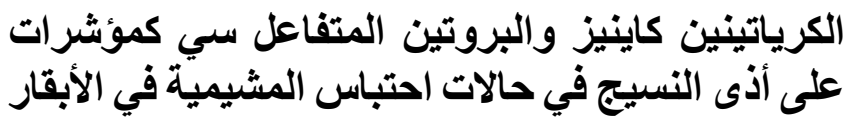

$$
\text { براء دريد الوتار، إيمان حياوي لازم و أسامة حازم الحياني الجراحة الموصل، العراق تتاسل الحيوان، كلية الطب البيطري، جامعة }
$$

الخلاصة

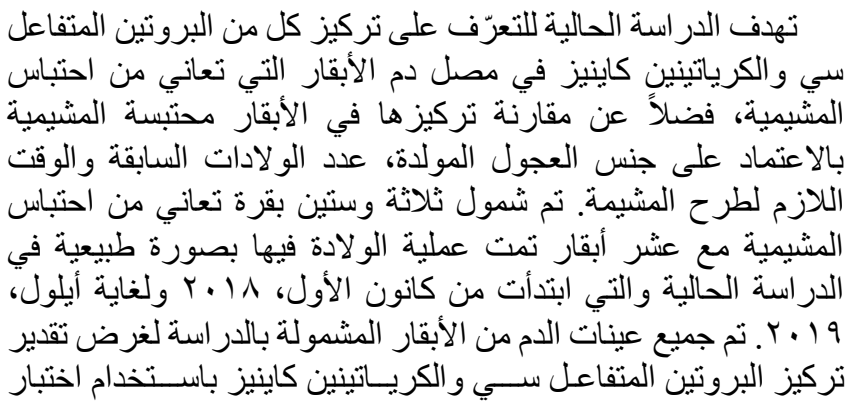




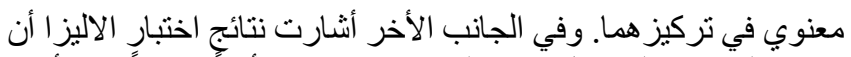

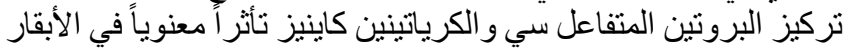

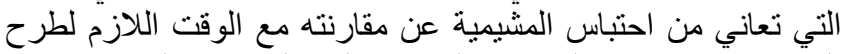

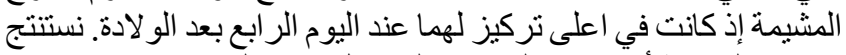

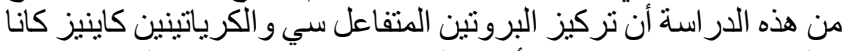

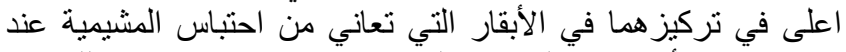

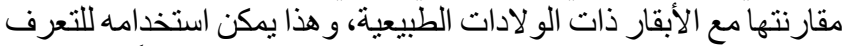

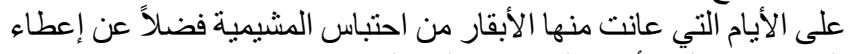
التنبؤ عن حالة الأبقار الصحية والتناسلية.
الاليز ا. أظهرت نتائج الدراسة الحالية أن تركيز البروتين المتفاعل سي التئي

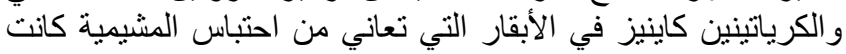

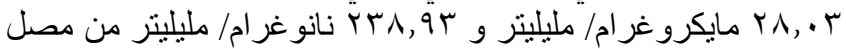

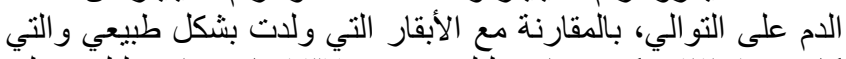

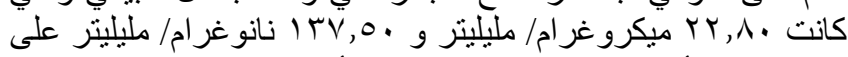

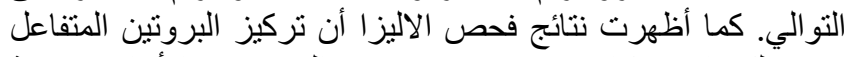

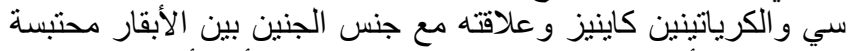

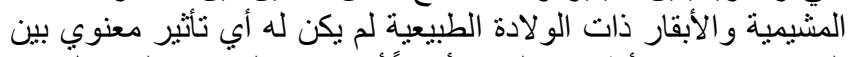

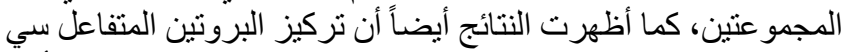

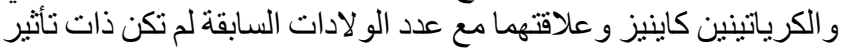

